\title{
Changes in structure and peptidase activity of rat small intestine induced by prednisolone
}

\author{
ALFRED J. WALL ${ }^{1}$ AND T. J. PETERS ${ }^{2}$ \\ From the Departments of Medicine and Pathology and the MRC Intestinal Malabsorption Group, Royal \\ Postgraduate Medical School, London
}

SUMMARY Chronic dietary administration of prednisolone to the adult rat caused alteration in morphology and enzyme activity of the small intestinal mucosa. Reduction of villous height, crypt depth, and surface epithelial cell height was accompanied by a significant increase in the specific activity of several jejunal peptidases.

The epithelial damage seen in the small intestine of patients with coeliac disease is related to the dietary ingestion of gluten. A deficiency of a peptidase capable of detoxifying gluten may be the underlying defect (Frazer, 1956). The intestinal mucosal damage responds to the dietary exclusion of gluten. Wall, Douglas, Booth, and Ptarse (1970a) successfully used prednisolone to treat adults with coeliac disease, and furthermore showed a return of peptidase activity to normal in the regenerated mucosa despite the continued ingestion of gluten. This study describes the morphological and enzymic effect of prednisolone in pharmacological doses on the small intestine of the normal adult rat.

\section{Methods}

Eight female Wistar albino rats weighing 180-200 g were fed prednisolone-21-phosphate in a daily dose of $0.15 \mathrm{mg}$ mixed with a standard diet (41B, E. Dixon and Sons, Ltd, Middlesex, England) taken ad libitum. Control animals were of similar weight and received the same diet. After four weeks animals were fasted overnight, killed by cervical dislocation, and the small intestine was removed.

\section{HISTOLOGY}

A $1 \mathrm{~cm}$ segment immediately distal to the duodenojejunal junction and immediately proximal to the ileocaecal junction was opened, orientated on flat Received for publication 6 April 1971.

${ }^{1}$ Present address: Department of Medicine, University of Chicago, 950 E. 59th St, Chicago, Illinois 60637 USA

${ }^{2}$ Present address: Department of Biochemical Cytology, The Rockefeller University, New York, New York 10021, USA paper, fixed in buffered $10 \%$ formal saline, dehydrated, and embedded in paraffin. Sections $4 \mu$ thick were stained with both haematoxylin and eosin and PAS. Crypt depth (muscularis mucosae to crypt mouth) and villous height (crypt mouth to villous tip) were measured in 20 consecutive well orientated areas as previously described (Wall, Middleton, Pearse, and Booth, 1970b). Epithelial cell height was assessed by measuring five adjacent cells on each side of the middle third of 10 consecutive well orientated villi.

\section{ELECTRON MICROSCOPY}

Specimens of intestine, approximately $1 \mathrm{~cm}$ in size, were immediately fixed for one hour in ice-cold phosphate-buffered osmium tetroxide, dehydrated, and embedded in Araldite epoxy resin. Epithelium from the middle third of the villus was sectioned at $600 \AA$, stained with uranyl acetate and lead citrate, and examined with an EM 6B electron microscope.

\section{HISTOCHEMISTRY}

Pieces of upper jejunum and lower ileum were orientated against a cube of rat liver, snap frozen, and stored in liquid nitrogen. Further pieces were fixed in buffered formol calcium at $4^{\circ} \mathrm{C}$ for 12 hours, washed and stored in gum sucrose at $4^{\circ} \mathrm{C}$. The activity of the following enzyme reactions was compared by simultaneous incubation of $6 \mu$ cryostat sections from control and treated rats: alkaline phosphatase, L-leucyl- $\beta$ naphthylamidase, E-600 resistant esterase, succinic dehydrogenase, NAD diaphorase, monoamine oxidase, glucose-6phosphatase, and non-specific esterase by methods 
described by Pearse (1968). The intensity of the reaction product was visually compared by two observers in control and treated tissues.

\section{ENZYMOLOGY}

Immediately after sacrifice the upper $15 \mathrm{~cm}$ of jejunum was washed with ice-cold $0.15 \mathrm{M} \mathrm{NaCl}$ and everted over a metal rod. The mucosa was scraped off with a glass slide and homogenized for $\mathbf{3 0}$ seconds in 10 volumes of ice-cold distilled water in an MSE homogenizer. The homogenate was then centrifuged at $3,000 \mathrm{~g}$ for $30 \mathrm{~min}$ and aliquots of the supernatant were stored at $-25^{\circ} \mathrm{C}$.

Peptidase activity was assayed by the automated kinetic method of Lenard, Johnson, Hyman, and Hess (1965) modified by Peters (1969), at a substrate concentration of $0.2 \mathrm{mM}$ in $0.067 \mathrm{M}$ phosphate buffer at $37^{\circ} \mathrm{C}$. Details of $p \mathrm{H}$ optima and appropriate cofactors are listed in Table I. The hydrolysis of 1 micromole peptide per hour represents 1 unit of activity. Activities of the lysosomal enzymes aryl sulphatase and pteroylpolyglutamate hydrolase were measured by the methods of Roy (1953) and Hoffbrand and Peters (1969) respectively. The activity of the brush border enzyme L-leucyl-

\begin{tabular}{lll}
\hline Peptide & pH Optimum & Activator \\
\hline Glycl-glycine & $7 \cdot 4$ & $0 \cdot 2 \mathrm{mM} \mathrm{Co}^{2+}$ \\
L leucyl-1 leucine & $8 \cdot 0$ & $0 \cdot 2 \mathrm{mM} \mathrm{Mn}^{2+}$ \\
L prolyl-glycine & $\mathbf{8 \cdot 4 ^ { 1 }}$ & $0 \cdot 2 \mathrm{mM} \mathrm{Mn} \mathbf{M n}^{2+}$ \\
Glycyl-glycyl-glycine & $\mathbf{7 \cdot 4}$ & $0 \cdot 1 \mathrm{mM} \mathrm{EDTA}$ \\
L leucyl-glycyl-glycine & $\mathbf{7 \cdot 4}$ & $0 \cdot 1 \mathrm{mM}$ EDTA \\
\hline
\end{tabular}

Table I Conditions for peptidase assay ${ }^{1} \mathrm{pH}$ optimum $>9.0$

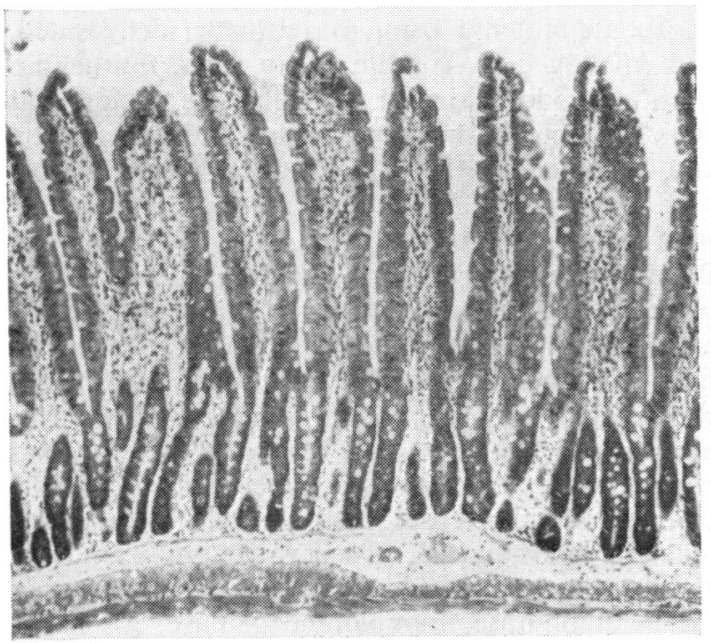

Bnaphthylamidase was measured by the method of Goldbarg and Rutenburg (1958). Protein estimations were by the method of Lowry, Rosebrough, Farr, and Randell (1951). Bovine serum albumin (Armour) was the standard.

\section{Results}

\section{HISTOLOGY}

The results are shown in Table II and Figure 1. A significant decrease of villous height and crypt depth was found in both jejunum and ileum of treated rats. Surface cell height was reduced significantly in the ileum and to a borderline degree of statistical significance in the jejunum. The thickness of the muscle coat was not quantified.

\section{ELECTRON MICROSCOPY}

No abnormalities were observed, and in particular no increase of endoplasmic reticulum or of microvillous size was seen.

\section{HISTOCHEMISTRY}

Only the leucyl- $\beta$ naphthylamidase reaction showed a change. A clear-cut increase in activity was demonstrated in both jejunum and ileum of the treated animals, although the spatial distribution of the enzyme was normal. The change was best seen in postfixed tissues, but was also observed in formalin prefixed tissues.

ENZYME STUDIES

A significant increase of both brush-border and soluble peptidase activity was seen in the treated

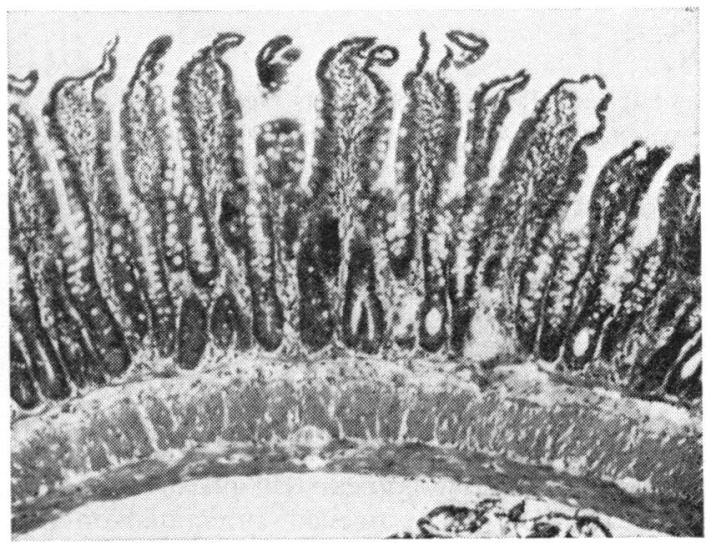

Fig. 1 Morphology of jejunum from control (left) and treated rats (above). Note the marked reduction of both villous height and crypt depth. Haematoxylin and eosin. Original magnification $\times 75$. 


\begin{tabular}{|c|c|c|c|c|}
\hline & Total Mucosal Thickness & Villous Height & Crypt Depth & Epithelial Cell Height \\
\hline $\begin{array}{l}\text { Jejunum } \\
\text { Control } \\
\text { Treated } \\
\text { Statistical significance }\end{array}$ & $\begin{array}{l}728 \pm 26 \\
466 \pm 24 \\
P<0.001\end{array}$ & $\begin{array}{l}475 \pm 26 \\
291 \pm 17 \\
P<0.001\end{array}$ & $\begin{array}{l}254 \pm 20 \\
175 \pm 16 \\
P=0.01\end{array}$ & $\begin{array}{l}32.1 \pm 1.1 \\
28.3 \pm 1.3 \\
P=0.05\end{array}$ \\
\hline $\begin{array}{l}\text { lleum } \\
\text { Control } \\
\text { Treated } \\
\text { Statistical significance }\end{array}$ & $\begin{array}{l}624 \pm 24 \\
339 \pm 30 \\
P=0.001\end{array}$ & $\begin{array}{l}335 \pm 14 \\
154 \pm 10 \\
P=0.001\end{array}$ & $\begin{array}{l}289 \pm 20 \\
189 \pm 32 \\
P<0.01\end{array}$ & $\begin{array}{l}24.9 \pm 0.7 \\
19.2 \pm 0.5 \\
P<0.001\end{array}$ \\
\hline
\end{tabular}

Table II Histological measurements of jejunum and ileum ${ }^{1}$

${ }^{1}$ Results are expressed in microns and are the means \pm SEM

\begin{tabular}{lccl}
\hline Substrate & Controls & Treated & Statistical Significance \\
\hline Glycyl-glycine & $1.91 \pm 0.10$ & $3.52 \pm 0.30$ & $\mathbf{P}=0.002$ \\
L leucyl-leucine & $22.1 \pm 1.2$ & $47.0 \pm 4.4$ & $\mathbf{P}<0.001$ \\
L prolyl-glycine & $0.54 \pm 0.02$ & $0.99 \pm 0.04$ & $\mathbf{P}=0.001$ \\
Glycyl-glycyl-glycine & $0.25 \pm 0.03$ & $0.39 \pm 0.03$ & $\mathbf{P}=0.01$ \\
L leucyl-glycyl-glycine & $5.25 \pm 0.34$ & $6 \cdot 25 \pm 0.94$ & $\mathbf{P}=0.01$ \\
L leucyl-8naphthylamide & $0.24 \pm 0.02$ & $0.49 \pm 0.02$ & $\mathbf{P}<0.001$ \\
\hline
\end{tabular}

Table III Peptidase activity of jejunal homogenates from treated rats and controls ${ }^{1}$

${ }^{1}$ Results are expressed in units/mg protein and are the means $\pm S E M$

\begin{tabular}{llll}
\hline Enzyme & Controls & Treated & $P$ \\
\hline $\begin{array}{l}\text { Aryl sulphatase } \\
\begin{array}{l}\text { Pteroyl- } \\
\text { polyglutamate } \\
\text { hydrolase }\end{array}\end{array}$ & $0.457 \pm 0.003$ & $0.0503 \pm 0.006$ & $P=0.48$ \\
\hline
\end{tabular}

Table IV Activity of lysosomal enzymes in jejunal homogenates from treated rats and controls ${ }^{1}$

${ }^{1}$ Results are expressed in units/mg protein and are the means \pm SEM

animals for all substrates tested (Table III). In contrast, there was no significant change in the activity of the two lysosomal enzymes tested (Table IV).

\section{Discussion}

The chronic dietary administration of prednisolone to the normal adult rat has here been shown to cause mucosal atrophy and a reduction in the height of intestinal epithelial cells. Corticosteroids in high dosage inhibit mitosis (Bucher, 1963; Hechter and Halkerston, 1965; Ragins and Wincze, 1969) and this effect may explain the mucosal atrophy. The eduction of epithelial surface cell height may also be due to the protein catabolic effect of corticosteroids (Izzo and Glasser, 1961).

In contrast to these morphological changes, significant increases of several jejunal peptidases were observed with both biochemical and histochemical methods. Such enzyme changes have not previously been described, although Talanti and
Hopsu (1961) noted decreased activity of leucyl$\beta$ naphthylamidase activity in rat gastric mucosa following adrenalectomy, and Schwartz, Robertson, and Holmes (1956) showed that glycyl-glycyl-glycinepeptidase activity in rat diaphragm was inhibited by adrenalectomy and restored to normal by cortisone. Pina Hamabata, and Laguna (1962) claimed that hydrocortisone stimulated the activity of this peptidase in vitro. However, Peters (1968) could not show this effect when a jejunal homogenate was incubated with hydrocortisone, but demonstrated inhibition of enzyme activity at pharmacological concentrations $\left(10^{-3} \mathrm{M}\right)$, an observation reported for other proteolytic enzymes by Bellamy and Leonard (1966).

The activity of other intestinal enzymes has been shown to be hormone sensitive. Moog and Grey (1968) demonstrated the induction of alkaline phosphatase in the duodenum of weanling mice by hydrocortisone, and Stifel, Herman, and Rosenweig (1969) demonstrated increased activity of several glycolytic enzymesin the jejunum of adult rats treated with oestrogen, progesterone, or testosterone. Wall et al (1970b) described increased histochemical activity of several brush border enzymes in the jejunum of rats treated with pharmacological doses of thyroid extract.

At first sight there is some apparent incongruity in our results. Although there was some evidence of impaired protein metabolism, reflected by structural changes in the mucosa, there was an increase in the activity of certain enzymes. Similar findings have, however, been noted in the regenerating rat liver, when the administration of hydrocortisone caused 
inhibition of mitosis and increased synthesis of RNA (Bucher, 1963).

Our study may have clinical implications. Inflammatory diseases of the gastrointestinal tract, such as pernicious anaemia, coeliac disease, regional enteritis, and chronic ulcerative colitis, are known to be responsive to corticosteroids. The beneficial effects of these hormones have been attributed to anti-inflammatory or anti-immune mechanisms. It is, however, possible that corticosteroids may induce peptidase activity in the intestinal cell, thereby facilitating proteolysis of toxic dietary or bacterial proteins. Further study of the mode of action of corticosteroids in human inflammatory intestinal diseases seems to be indicated.

The interest and advice of Professors C. C. Booth and A. G. E. Pearse are gratefully acknowledged. Dr A. V. Hoffbrand kindly performed the pteroyl polyglutamate hydrolase assays. T.J.P. is in receipt of a Medical Research Council fellowship. A.J.W. was supported by a Commonwealth medical fellowship and by the Wellcome Foundation.

\section{References}

Bellamy, D., and Leonard, R. A. (1966). The action of corticosteroids on proteolysis. Biochem. J., 98, 581-586.

Bucher, N. L. R. (1963). Regeneration of mammalian liver. Int. Rev. Cytol., 15, 245-300.

Frazer, A. C. (1956). Discussion on some problems of steatorrhoea and reduced stature. Proc. roy. Soc. Med., 49, 1009-1013.

Goldbarg, J. A., and Rutenburg, A. M. (1958). The colorimetric determination of leucine aminopeptidase in urine and serum of normal subjects and patients with cancer and other diseases Cancer (Philad.), 11, 283-291.
Hechter, O., and Halkerston, T. D. (1965). Effects of steroid hormones on gene regulation and cell metabolism. Ann. Rev. Physiol. 27, 133-162.

Hoff brand, A. V., and Peters, T. J. (1969). The subcellular localisation of pteroyl polyglutamate hydrolase and folate in guinca pig intestinal mucosa. Biochim. biophys. Acta (Amst.), 192, 479-485.

Izzo, J. L., and Glasser, S. R. (1961). Comparative effects of glucagon, hydrocortisone and epinephrine on the protein metabolism of the fasting rat. Endocrinology, 68, 189-198.

Lenard, J., Johnson, S. L., Hyman, R. W., and Hess, G. P. (1965). A continuous automatic method for the study of rate of hydrolysis of peptides and amides. Analyt. Biochem., 11, 30-41.

Lowry, O. H., Rosebrough, N. J., Farr, A. L. and Randell, R. J. (1951). Protein measurement with Folin phenol reagent.J.biol. Chem., 193, 265-275.

Moog, F., and Grey, R. D. (1968). Alkaline phosphatase isozymes in the duodenum of the mouse: attainment of pattern of spatial distribution in normal development and under the influence of cortisone or actinomycin D. Develop. Biol., 18, 481-500.

Pearse, A. G. E. (1968). Histochemistry. Theoretical and Applied, 3rd ed., Vol I. Churchill, London.

Peters, T. J. (1968). Unpublished observations.

Peters, T. J. (1969). Application of an improved kinetic assay system to the study of the subcellular localisation of peptidases. J. Physiol. (Lond.), 202, 13 P.

Pina, E., Hamabata, A., and Laguna, J. (1962) Effect of low concentration of steroids on the activity of glycylglycine dipeptidase in vitro Biochem. biophys. Res. Commun., 9, 447-450.

Ragins, H., and Wincze, F. (1969). Effect of cortisone on the turnover of gastric parietal cells in the mouse. Endocrinology, 84, 83-90.

Roy, A. B. (1953). The sulphatase of ox liver. 1. The complex nature of the enzyme. Biochem. J., 53, 12-15.

Schwartz, T. B., Robertson, M. C., and Holmes, L. B. (1956). Adrenocortical influences on dipeptidase activity of surviving rat diaphragm. Endocrinology, 58, 453-460.

Stifel, F. B., Herman, R. H., and Rosensweig, N. S. (1969). Effect of estrogen, progesterone, and testosterone on rat jejunal glyco lytic enzymes. Fed. Proc., 28, 805.

Talanti, S., and Hopsu, V. K. (1961). Leucine aminopeptidase in the gastric mucosa of the adrenalectonised rat. Endocrinology, 68, 184-185.

Wall, A. J., Douglas, A. P., Booth, C. C., and Pea-se, A. G. E. (1970a). Response of the jejunal mucosa in adult cceliac disease. to oral prednisolone. Gut, 11, 7-14.

Wall, A. J., Middleton, W. R. J., Pearse, A. G. E., and Booth, C. C. (1970b). Intestinal mucosal hyperplasia following induced hyperthyroidism in the rat. V'irchow's Archiv. (Zellpath.), 6, 79-87. 